\title{
Massive induction of apoptosis of multicellular tumor spheroids by a novel compound with a calmodulin inhibitor-like mechanism
}

\author{
Chitralekha Mohanty' ', Walid Fayad ${ }^{1,3}$, Maria Hägg Olofsson'1 , Rolf Larsson², Angelo De Milito', Mårten Fryknäs² and \\ Stig T. Linder ${ }^{1,2^{*}}$ \\ ${ }^{*}$ Correspondence: Stig.Linder@ki.se \\ ${ }^{1}$ Cancer Center Karolinska, Department of Oncology and Pathology, Karolinska Institute and Hospital, \\ S-171 76 Stockholm, Sweden. \\ ${ }^{2}$ Department of Medical Sciences, Division of Clinical Pharmacology, University Hospital, Uppsala University, \\ S-751 85 Uppsala, Sweden. \\ ${ }^{3}$ Drug Bioassay-Cell Culture Laboratory, Department of Pharmacognosy, Pharmaceutical and Drug Industries Division, \\ National Research Center, Dokki, Giza 12622, Egypt.
}

\begin{abstract}
Background: A number of anticancer drug candidates have been identified by cell-based screens utilizing tumor cells grown in monolayer culture. Since such cultures are poor models of 3-D tumor micro-environments, we here aimed to identify novel compounds showing anti-proliferative activity on multicellular spheroids.

Methods: A chemical library was used to screen for compounds capable of reducing viability and inducing apoptosis of colon carcinoma cells grown as multicellular spheroids. Assessment of possible mechanism of action was performed using gene expression profiling.

Results: The screen identified NSC647889 as a potent apoptotic compound. NSC647889 induced dramatic increases in tumor cell apoptosis in multicellular spheroids compared to standard antineoplastic agents. Interestingly, quiescent cells in spheroid cores were resistant to NSC647889-induced apoptosis and appeared to die by other mechanisms. The cellular phenotypic response to NSC647889 was similar to that of known calmodulin inhibitors and the compound stimulated rapid increases of intracellular calcium levels. NSC647889 was, however, not a direct inhibitor of calmodulin-dependent calcineurin activity. Finally, NSC647889 induced tumor apoptosis in a xenograft tumor model.

Conclusions: Novel drugs that show considerably stronger cytotoxic activity in 3-D culture compared to standard agents can be identified. Further development of such drugs may be a useful strategy for improved treatment of solid tumors.
\end{abstract}

Keywords: Multicellular tumor spheroids, apoptosis, calcium signaling, cmap

\section{Introduction}

It is well known that a significant discrepancy exists between the efficacy of anticancer drugs in vitro and in vivo [1]. This discrepancy could, in part, be due to the three dimensional (3-D) nature of tumors as compared to the two dimensional (2-D) nature of standard cell culture systems. To be effective in vivo, anticancer drugs must penetrate into tumor cell masses to reach cancer cells at toxic concentrations. Experiments using multicellular in vitro models have shown that the tissue is a barrier to the distribution of many anticancer agents [2-4]. Furthermore, tumor cells exist in an organized 3-D matrix, where nutrients and oxygen will not be easily accessible to all cells. Differences in proliferation, gene expression pattern, cell surface receptor expression and extracellular matrix synthesis of cells are grown in 2-D or 3-D culture have indeed been reported [5-7]. An outstanding question is which strategy to use to achieve optimal anti-proliferative effect on hypoxic and nutrition limited cells present in solid tumors. An increased understanding is expected to result in the development of drugs with an improved therapeutic efficacy.

Multicellular spheroids (MCS) and other 3-D culture systems mimic human solid tumors better than 2-D monolayer cultures [8-11]. MCS are known to be more resistant to drug effects compared to monolayer cultures [12-15] and many clinically used drugs show limited potency on spheroids $[1,16,17]$. Therefore, MCS are better suited than monolayer cultures for drugs screening projects aimed to identify compounds active on solid tumors. We have established a screening procedure with good assay performance for the identification of drugs that induce apoptosis of tumor cells grown in MCS [18]. We here describe a novel small molecule (NSC647889) 
capable of inducing an unprecedented extent of apoptosis in MCS. Interestingly, however, the novel drug did not induce apoptosis in the core areas of MCS, suggesting that cells in hypoxic and nutrient limited areas are resistant to apoptosis. The gene expression profile induced by this drug suggested a molecular mechanism of action similar to that of calmodulin inhibitors. The result of our study show that novel drugs can be identified which show considerably stronger apoptotic activity on tumor cells grown in 3-D culture compared to standard agents.

\section{Materials and methods Compound library}

The Mechanistic set was obtained from the Developmental Therapeutics Program of the US National Cancer Institute (http://www.dtp.nci.nih.gov). All compounds were dissolved in DMSO. A final concentration of $0.5 \%$ DMSO was reached in cell cultures; control wells received solvent only.

Cell culture, generation of spheroids and screening HCT116 colon carcinoma cells were maintained in McCoy's $5 \mathrm{~A}$ modified medium $/ 10 \%$ fetal calf serum at $37^{\circ} \mathrm{C}$ in $5 \%$ $\mathrm{CO}_{2}$. Spheroids were prepared as described previously [19]. Briefly, a cell suspension containing 10,000 cells was added to each well of poly-HEMA-coated 96 -well plates. Wells were then filled by adding culture medium to acquire a convex surface. Plates were inverted to allow the cells to sediment to the liquid-air interface. After $24 \mathrm{~h}$ incubation on a rotatory shaker, plates were returned to normal and excess medium was removed. Plates were then incubated for a further 4 days. This procedure was both for screening and all other experiments. At the day of treatment, the medium was removed and $200 \mu \mathrm{L}$ fresh medium was added per well. After 24 hours of drug treatment, NP40 was added to the culture medium to $0.1 \%$ in order to extract caspase-cleaved K18 (ccK18) from spheroids and to include material released to the medium from dead cells. ccK18 was determined using $25 \mu \mathrm{L}$ medium/extract using the M30 Apoptosense ${ }^{\oplus}$ ELISA [20] (www.peviva.com, VLVbio AB, Sundbyberg, Sweden). Signals were factorised to percent of a staurosporine reference (quadruple wells used on each plate at $1 \mu \mathrm{M}$ ). Viability measurements were performed using the acid phosphatase (APH) method described by Friedrich et al., [21]. Background activity was subtracted.

\section{Immunological assays}

Spheroids produced by the hanging drop method in 96 well plates were fixed in paraformaldehyde, dehydrated, embedded in paraffin and sectioned. Each sample contained 32 spheroids (spheroids from each 96 well plate were pooled into 3 groups). The sections were deparaffinized with xylene, rehydrated and microwaved and then incubated over-night with the monoclonal primary antibodies diluted in 1\% (wt/ vol) bovine serum albumin and visualized by standard avidin-biotin-peroxidase complex technique (Vector
Laboratories, Burlingame, CA, USA). Counterstaining was performed with Mayer's haematoxylin. Antibody against active caspase-3 was from Pharmingen and used at 1:50, Antibody to Ki67 was from Dako (Glostrup, Denmark) and to p27/Kip1 from BDPharmingen (San Jose, CA). Hypoxic regions were detected after incubation of MCS with $100 \mathrm{mM}$ of pimonidazole hydrochloride. Sectioned spheroids were incubated with Hypoxyprobe-1 (HPI Inc., Burlington, MA, USA) to detect pimonidazole adducts. Serial sectioning was not required since the hanging drop procedure generates spheroids of homogenous size [19].

\section{Connectivity map}

The Connectivity Map (Cmap) (www.broad.mit.edu/cmap) build 02 contains genome-wide expression data for 1300 compounds (6100 instances, including replicates, different doses and cell lines). We followed the original protocol using MCF-7 breast cancer cells as described by Lamb et al., [22]. Briefly, cells were plated in 6-well plates at a density of $0.4 \mathrm{x}$ $10^{6}$ cells per well. Cells were left to attach for $24 \mathrm{~h}$, followed by exposure to NSC647889 at a final concentration of $10 \mu \mathrm{M}$, or to vehicle control (DMSO). After $6 \mathrm{~h}$ treatment, the cells were washed with PBS and total RNA was prepared using RNeasy miniprep kit (Qiagen, Chatsworth, CA). Starting from two micrograms of total RNA, gene expression analysis was performed using Genome U133 Plus 2.0 Arrays according to the GeneChip Expression Analysis Technical Manual (Rev. 5, Affymetrix Inc., Santa Clara, CA). Raw data was normalized with MAS5 (Affymetrix) and gene expression ratios for drug treated vs. vehicle control cells were calculated to generate lists of regulated genes. Only probes present on HG U133A were used, for Cmap compatibility. The 40 most up and down regulated genes (i.e., probes) for each compound were uploaded into the CMAP and compared to the 6,100 instances in the Cmap database, to retrieve a ranked compound list. Raw and normalized data will be made available at Gene Expression Omnibus.

\section{Calcineurin activity assay}

HCT116 cells were exposed to NSC647889 $(10 \mu \mathrm{M})$ or DMSO vehicle control for 1 hour. W7-treated cells (10 $\mu \mathrm{M})$ were used as a positive control. Phosphatase assay was performed according to the manufacturer's instructions of the calcineurin cellular activity assay kit (Calbiochem, Merck4Biosciences). Cells were lysed using cold lysis buffer (50 mM Tris, 1 mM DTT, 0.1 mM EDTA, 0.1 mM EGTA, 0.2\% NP-40, pH 7.5) freshly supplemented with protease inhibitor from the kit. Lysates were cleared by centrifugation at 15,000 rpm for 30 mins at $4^{\circ} \mathrm{C}$ and the protein concentrations were measured by the Bradford assay (Bio-Rad, Richmond, CA, USA). The RIl phosphopeptide substrate (Asp-Leu-Asp-ValPro-Ile-Pro-Gly-Arg-Phe-Asp-Arg-Arg-Val-pSer-Val-Ala-AlaGlu) was activated with calmodulin in the assay buffer (200 $\mathrm{mM} \mathrm{NaCl}, 100 \mathrm{mM}$ Tris, $12 \mathrm{mM} \mathrm{MgCl} 2,1 \mathrm{mM} \mathrm{CaCl} 2,1 \mathrm{mM}$ DTT, $0.05 \% \mathrm{NP}-40, \mathrm{pH} 7.5$ ) for $10 \mathrm{~min}$ at $30^{\circ} \mathrm{C}$. Supernatants 
were added to the reaction mixture and incubated for 30 mins at $30^{\circ} \mathrm{C}$. EGTA in the assay buffer was used to distinguish between calcineurin and other phosphatases as recommended by the kit manufacturer. The enzyme activity was measured as phosphatase released per mg of protein from the substrate.

\section{Calcium uptake measurement}

A Fluo-4 Direct Calcium Assay Kit (Molecular Probes) was used to measure the uptake of extracellular calcium ions. HCT116 cells were treated with $10 \mu \mathrm{M}$ NSC647889, $10 \mu \mathrm{M}$ W7 or DMSO (vehicle control) for 1 hour after which the cells were loaded with the Fluo-4 direct calcium assay reagent supplemented with probenecid, following the manufacturer's instruction and incubated for 60 seconds. The fluorescence was measured at excitation and emission of $465 \mathrm{~nm}$ and $535 \mathrm{~nm}$ respectively in a Tecan multiplate reader.

\section{Treatment of mouse xenografts and determination of tumor-derived $\mathrm{K} 18$ in mouse plasma}

A FaDu head-neck carcinoma model (p53mut) was used for testing of in vivo antitumor activity. This model has previously been validated to be useful for determining human tumor cell apoptosis in SCID mice using blood samples [23]. FaDu cells express high levels of K18 which is released to the extracellular compartment and into the blood from dying cells [23]. When FaDu tumors had grown to a size of approximately $400 \mathrm{~mm}^{3}$, mice were subcutaneously injected with NSC647889 dissolved in DMSO (final dose 5 $\mathrm{mg} / \mathrm{kg}$ ). Mice were sacrificed 48 hours after injection of drug and EDTA-plasma was collected. Caspase-cleaved K18 (K18-Asp396) and total K18 were measured in 12.5 $\mu \mathrm{L}$ plasma using the Peviva M30-Apoptosense and M65 ELISA assays (www.peviva.com, VLVbio AB, Sundbyberg, Sweden) as described [23]. Each sample was mixed with $0.4 \mathrm{~mL}$ of heterophilic blocking reagent (HBR-Plus purified, part\#3KC579; Scantibodies laboratory Inc, Santee CA, USA). Animal experiments were conducted in full accordance with Swedish governmental statutory regulations on animal welfare under permission from ethical committees.

\section{Results}

Screening multicellular tumor spheroids for apoptosisinducing compounds identified the compound NSC647889

Five days after seeding HCT116 colon carcinoma cells in 96 well plates for formation of multicellular spheroids (MCS), spheroids showed a compact morphology and a diameter of $\sim 500 \mu \mathrm{m}$ (Figure 1A). MCS contained a hypoxic core consisting of non-proliferating cells (Figure 1A). The response of HCT116 MCS to three anticancer agents, cisplatin, melphalan and vinblastine is shown in (Figure 1B). These drugs elicited only limited activation of caspase- 3 at the spheroid periphery, consistent with previous reports $[24,25]$.
Note, however, that DNA damaging drugs such as cisplatin induce complex cellular responses (i.e., both apoptosis and senescence $[26,27])$. Therefore, the ability of cisplatin to reduce clonogenicity of MCS was larger than expected from the limited induction of apoptosis (see Figure $2 \mathrm{C}$ below; discussed in [25]).

HCT116 MCS were used to screen the NCI Mechanistic Set (827 compounds) for compounds that induce apoptosis. This library has been preselected for compounds with antiproliferative activity in the $\mathrm{NCl} 60$ cell line screen. Apoptosis was assessed as generation of an endogenous apoptosis product, caspase-cleaved keratin 18 (ccK18) [18]. In a secondary screen, 29 compounds were tested both for their ability to induce apoptosis and to induce loss of cell viability (Figure 1C). The most active compound found in the secondary screen was NSC647889 (N-(17b-dimethylamino-3b-androstanyl)- $\mathrm{N}^{\prime}$-[2-phenyl1-(2-thiazolyl)ethyl]urea). Compounds with scaffolds similar to NSC647889 have not previously been described to induce apoptosis of tumor cells. NSC647889 has a molecular weight of 548.8 Dalton (Figure 1D).

\section{NSC647889 is strongly apoptotic to spheroids}

Dose response determination of induction of apoptosis and loss of cell viability are shown in (Figures 2A and 2B). An 2.5 -fold difference was observed in the potency of inducing loss of cell viability between monolayer and spheroid cultures (Figure 2B). The clonogenicity of cells dispersed from MCS exposed to $10 \mu \mathrm{M}$ NSC 647889 was $<5 \%$ of that of cells dispersed from solvent-treated MCS (Figure 2C).

The ability of NSC647889 to induce apoptosis in MCS was examined by sectioning spheroids exposed to a concentration of $10 \mu \mathrm{M}$, followed by staining for active caspase-3 (Figure 3). At 6 h of exposure to NSC647889, increased apoptosis was observed of cell populations 0-100 $\mu \mathrm{m}$ from the spheroid surface. Interestingly, apoptosis was not observed at deeper layers at later time points (8 and $10 \mathrm{~h}$ ). At even later time-points, MCS disintegrated and could not be sectioned. We conclude that $10 \mu \mathrm{M}$ NSC647889 induced an apoptotic response in $\sim 80 \%$ of the cells in HCT116 spheroids (calculated on volume and assuming the same cell volume in different layers) whereas clonogenicity was reduced to $\sim 1 \%$ (Figure $2 \mathrm{C}$ ).

NSC647889 induces a phenotypic response similar to that of calmodulin inhibitors

To generate hypotheses regarding the molecular mechanisms of action of NSC647889, we used the Connectivity Map (Cmap) [22], a large compendium of gene expression signatures from drug-treated tumor cell lines. The gene expression response to NSC647889 was most similar to that of the calmodulin antagonist calmidazolium (Figure 4A). Furthermore, the expression profile was also similar to those of a number of other compounds reported to be 

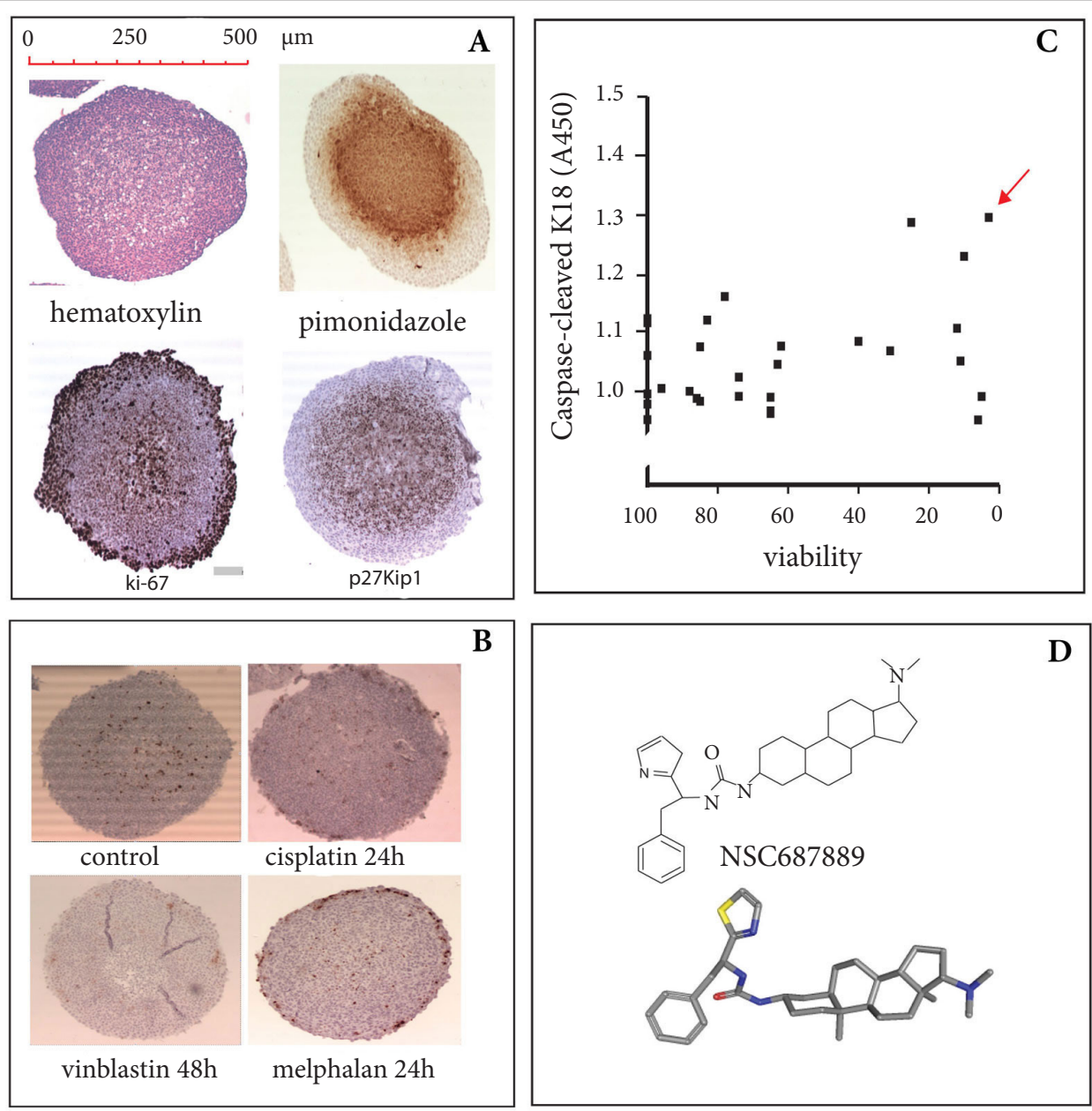

Figure 1. Identification of NSC647889 by spheroid screening. (A). Sections of HCT116 multicellular spheroids (MCS) 5 days after seeding of cells in hanging drops. Sectioned MCS were stained by hematoxilin, for pimonidazole adducts and for Ki67 and p27 $7^{\mathrm{Kip} 1}$ as indicated. (B). HCT116 MCS are resistant to standard chemotherapeutical drugs. MCS were exposed to $10 \mu \mathrm{M}$ cisplatin, $1 \mu \mathrm{M}$ vinblastine or $10 \mu \mathrm{M}$ melphalan for 24 or $48 \mathrm{~h}$, sectioned and stained by an antibody to active caspase-3. (C). Identification of NSC647889 using spheroid screening. A selected subset of the NCI Mechanistic Set was used to treat HCT116 colon carcinoma cells at $5 \mu \mathrm{M}$ of each compound. Viability and apoptosis induction was assessed for each compound at 24 h. Viability was determined using the acid phosphatase [21] (plotted right to left) and M30 Apoptosense ${ }^{\oplus}$ methods [45]. (D). Structure of NSC647889 (N-(17ß-dimethylamino-3 $\beta$ androstanyl)-N'-[2-phenyl-1-(2thiazolyl)ethyl]urea). Lower structure derived using Marvin Sketch for Mac. The compound has a molecular weight of 548.8 Daltons, a XLogP of 7.3, 6 rotable bonds and a topological surface area of $85.5 \AA^{2}$.

calmodulin antagonist such as phenoxybenzamine [28] and trifluoperazine [29,30], thioridazine [31] and prochlorperazine [32].

We determined $\mathrm{Ca}^{2+} /$ calmodulin-dependent calcineurin (Ser/Thr protein phosphatase 2B (PP-2B)) activity in cells exposed to NSC647889. The assay was based on the phosphopeptide substrate Asp-Leu-Asp-Val-Pro-Ile-ProGly-Arg-Phe-Asp-Arg-Arg-Val-(phospho)Ser-Val-Ala-AlaGlu. To distinguish calcineurin from other phosphatases recognizing the same substrates, assays were performed in the presence and absence of EGTA. In contrast to the calmodulin antagonist W7, and contrary to our working hypothesis, NSC647889 increased calcineurin activity in HCT116 cells (Figure 4B).

\section{NSC647889 increases intracellular calcium conce- ntrations}

The increased activity of calcineurin in NSC647889-exposed cells was hypothesized to be due to increases in cellular calcium. Cellular $\mathrm{Ca}^{2+}$ overload is known to trigger apoptotic cell death [33], potentially explaining the mechanism of cytotoxic activity. We determined intracellular calcium $\left(\mathrm{Ca}^{2+}\right)$ using the probe Fluo-4. Increased concentration of $\mathrm{Ca}^{2+}{ }_{i}$ were indeed observed after $1 \mathrm{~h}$ of drug exposure (Figure 5). The 


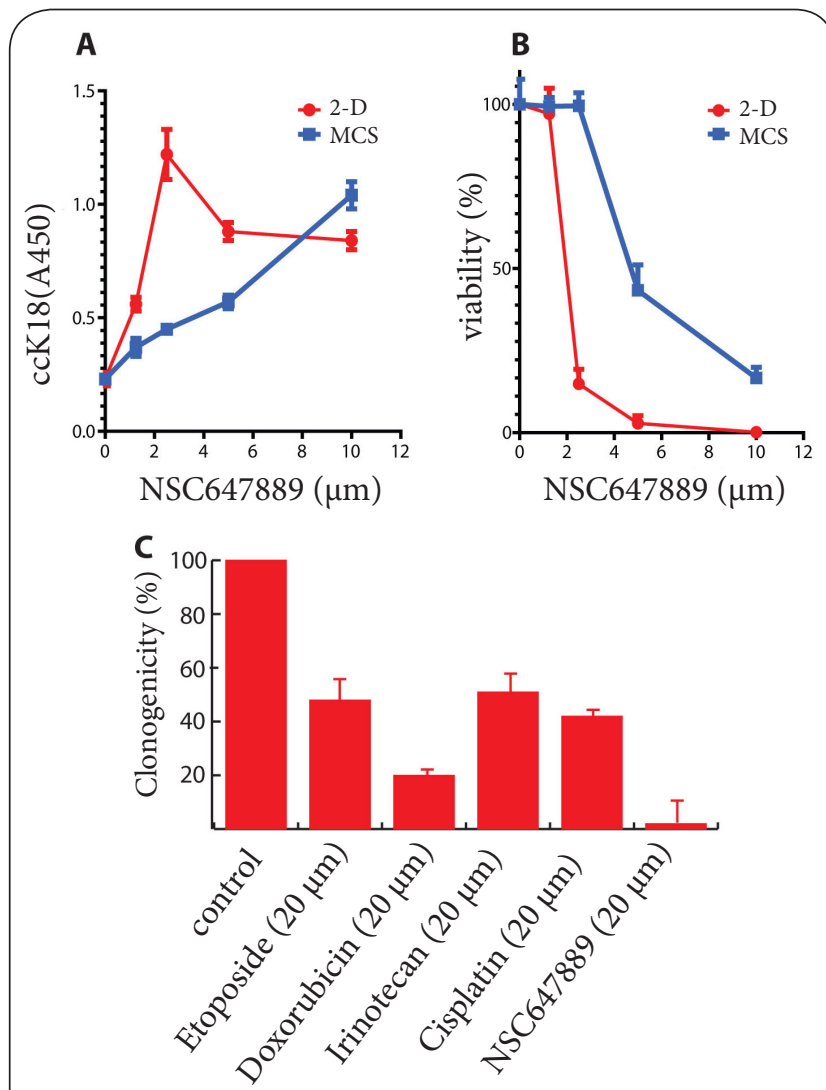

Figure 2. Induction of loss of viability and apoptosis in spheroids by NSC647889. Dose response to NSC647889 using the A M30 Apoptosense ELISA to determine apoptosis and B the acid phosphate spheroid test [21] to determine viability. Red symbols: monolayer cultures; blue symbols: spheroids. C. Loss of cell clonogenicity after treatment with NSC647889 or standard chemotherapeutical agents. Spheroids were exposed to the indicated compounds for $6 \mathrm{~h}$, cells were dispersed and seeded at low density for assessment of clonogenicity.

dose-response relationships of the increases in $\left[\mathrm{Ca}^{2+}{ }_{\mathrm{i}}\right]$ and induction of cell death/apoptosis were similar (Figures 2 and $\mathbf{5}$ ).

\section{Assessment of in vivo apoptotic activity}

We were interested in determining whether NSC647889 shows antitumor activity. The drug has a low solubility in aqueous solution (XLogP $=7.3$ ) and could not be formulated for repeated injections. We therefore used NSC647889 dissolved in DMSO and injected the drug s.c. ( $5 \mathrm{mg} / \mathrm{kg}$ ). This approach is not feasible for performing standard tumor growth inhibition experiments that require repeated drug injections. Since NSC647889 elicits generation of ccK18 in vitro (Figures 1 and 2), we examined whether the drug induces increased levels of circulating ccK18 in SCID mice with FaDu head-neck carcinoma xenografts. FaDu xenografts were chosen (instead of HCT116) due to previous findings of this model releasing large amounts of K18 after treatment with cytotoxic drugs [23]. The relative level of ccK18 in relation

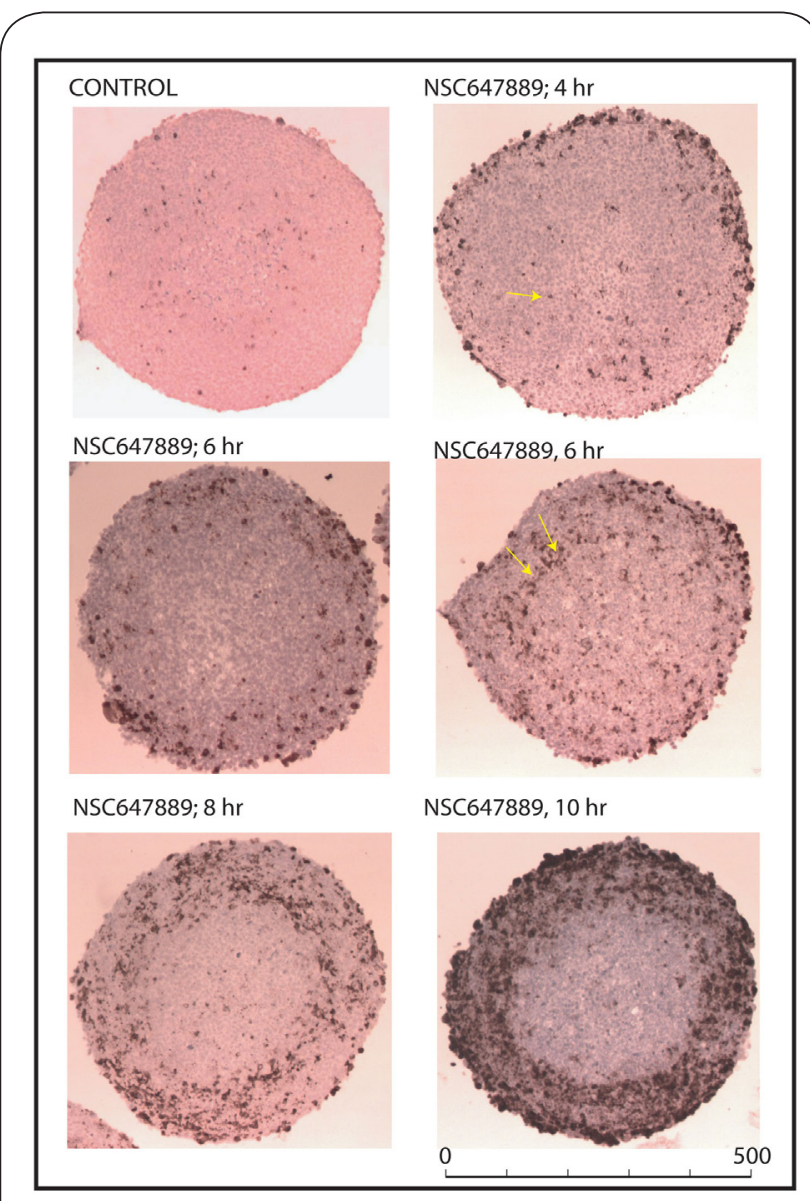

Figure 3. NSC647889 induces wide-spread activation of caspase-3 in spheroids. Spheroids were fixed and sectioned at different times after drug exposure $(10 \mu \mathrm{M})$ and stained for active caspase-3. The hanging drop technique was used for generation of spheroids and the largest spheroid diameters were photographed. to total $\mathrm{K} 18$ reflects cell death mode (apoptosis/necrosis) [34], and we also determined total plasma K18 [34,35]. The specificity of the antibodies to human K18 makes this a sensitive method for determination tumor apoptosis/cell death independently of host toxicity in mouse xenograft models [23]. Statistically significant increases in both ccK18 and total K18 were observed 48 hours after injection of NSC647889 (Figure 6), showing induction of tumor apoptosis and providing proof-of-principle for antitumor activity.

\section{Discussion}

Screening of the $\mathrm{NCl}$ Mechanistic Set identified the compound NSC647889 to be strongly apoptotic to HCT116 colon carcinoma multicellular spheroids. Apoptosis induction in spheroids was dramatic compared to that observed using standard compounds, and the strongest spheroid activity encountered by our laboratory. The scaffold of NSC647889 has to our knowledge not been previously reported to show 


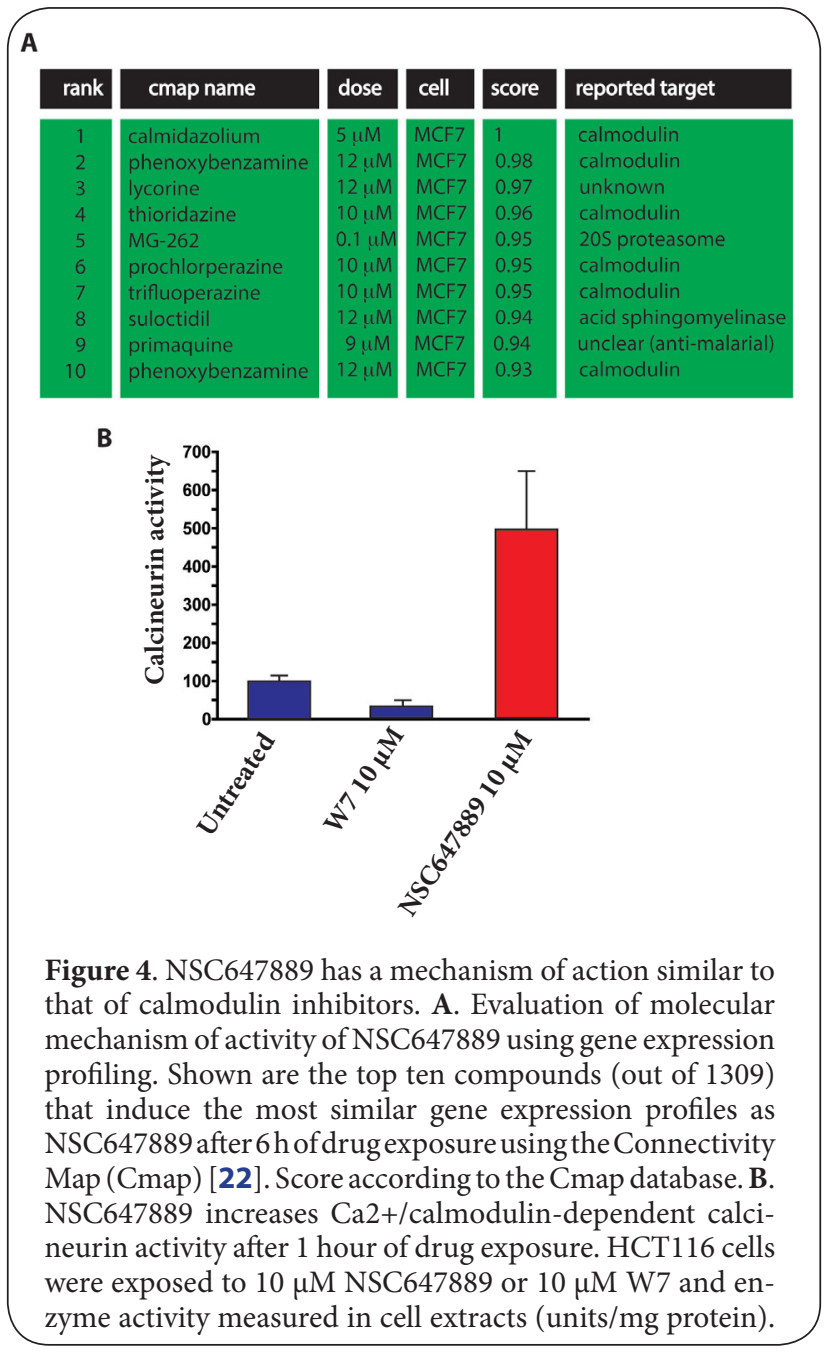

antineoplastic activity. NSC647889 shows antiproliferative activity in the $\mathrm{NCl} 60$ cell panel (average Gl50: $1.1 \mu \mathrm{M}$; strongest activity on acute lymphoblastic leukaemia, promyelocytic leukemia and chronic myelogenous leukemia cell lines (http://dtp.nci.nih.gov/)). We previously reported that compounds active on multicellular spheroids generally are hydrophobic [19] and the hydrophobicity (XLogP 7.3) of NSC647889 is consistent with this observation. The high degree of hydrophobicity complicated systematic in vivo assessments of antineoplastic effects. We were, however, able to document induction of tumor apoptosis at a dose of $5 \mathrm{mg} / \mathrm{kg}$ using circulating cell death biomarkers (Figure 6). This was close to the maximally tolerated dose $(10 \mathrm{mg} /$ $\mathrm{kg}$ ) and it is unclear whether NSC647889 has a sufficient therapeutic window to make it a candidate for further development.

The Cmap analysis suggested a mechanism of action related to calmodulin inhibition. A number of CaM antagonists have been described (for reviews, see [36,37]) and the CaM antagonist calmidazolium has previously been

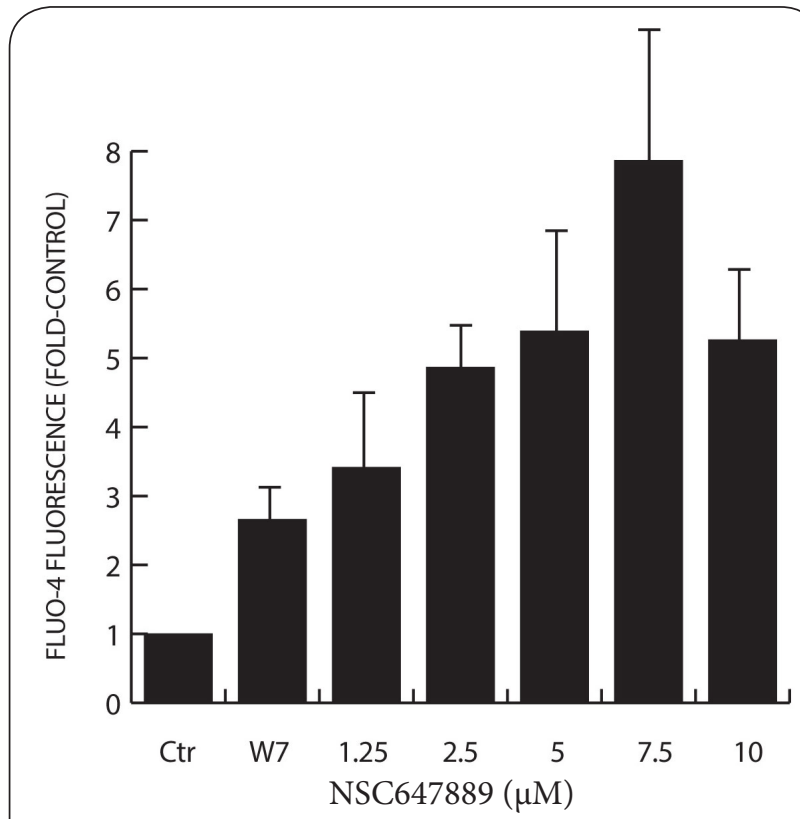

Figure 5. NSC647889 stimulates increasesin intracellularcalcium. HCT116 cells were exposed to different concentration of NSC647889 or W7 $(10 \mu \mathrm{M})$ for $1 \mathrm{~h}$ and cellular calcium was determined using Fluo-4.
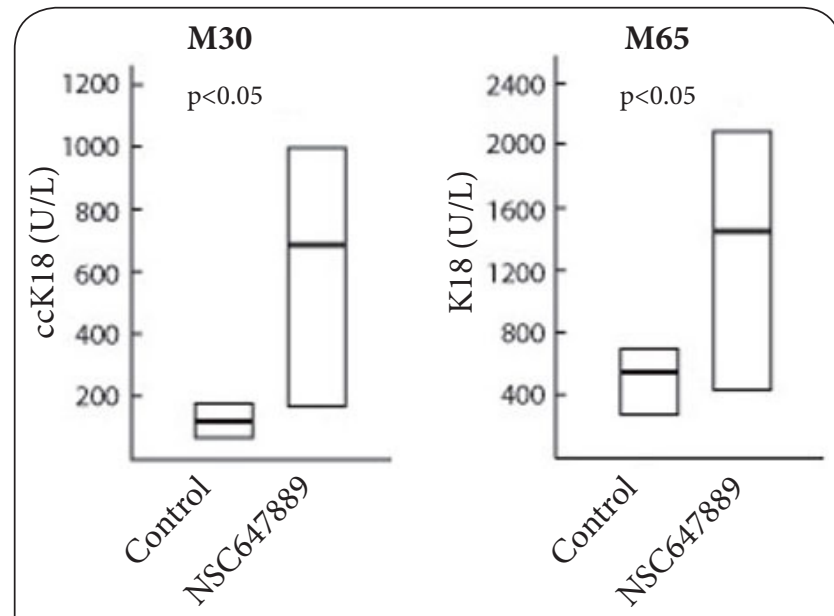

Figure 6. In vivo induction of apoptosis by NSC647889 in $\mathrm{FaDu}$ head-neck carcinoma xenografts. SCID mice were injected with $5 \mathrm{mg} / \mathrm{kg}$ NSC647889 (subcutaneous injection, compound dissolved in DMSO). Levels of human caspasecleaved (ccK18, K18 cleaved at DALD-396 by caspases) and total K18 were determined in mouse plasma after $48 \mathrm{~h}$ by ELISA. The antibodies used to detect ccK18 and K18 in plasma do not recognize the mouse protein. Control mice were injected with DMSO.

found to induce apoptosis [38]. NSC647889 did not, however, inhibit CaM-dependent calcineurin (protein phosphatase 2B) activity in cells. Rather, calcineurin phosphatase activity was stimulated in exposed cells. These increases are likely to be due to elevations of intracellular calcium concentrations. 
Mohanty et al. Journal of Cancer Therapeutics \& Research 2013, http://www.hoajonline.com/journals/pdf/2049-7962-2-19.pdf

A number of ion channels are regulated by $\mathrm{CaM}$ and $\mathrm{CaM}$ can be considered as an integral ion-channel subunit [39]. lon channels regulated by calmodulin include the voltagegated calcium channel (VGCC, CaV) and ryanodine and IP3 receptors [40]. It is therefore possible that the similar gene expression pattern induced by NSC647889 and CaM inhibitors reflect a general cellular response to influx of $\mathrm{Ca}^{2+}$ into cells during the early phases of the apoptotic process. Sustained increases in $\left[\mathrm{Ca}^{2+}\right]$ are well known to be associated with apoptosis $[33,41,42]$ but generally occurring during late stages [43]. The consequences of these more universal changes of calcium fluxes during the apoptotic execution phases will not be detected by the Cmap approach which uses $6 \mathrm{~h}$ exposure times.

Activation of caspase- 3 was not observed in tumor spheroid core regions. However, the same concentration $(10 \mu \mathrm{M})$ of drug that was incapable of inducing apoptosis in core cells (a cell population constituting $\sim 20 \%$ of total) was found to reduce clonogenicity of dispersed MCS cells to $\sim 1 \%$. These findings are likely to be explained by core cells dying by other mechanisms (i.e., presumably necrosis). Analysis of the pattern of apoptosis-induction after drug treatment (Figure 3 ) showed a sharp "boundary" at a depth of $\sim 100 \mu \mathrm{m}$, below which the compound did not induce caspase- 3 activation. This "boundry" was visible after $6 \mathrm{~h}$ and remained essentially at the same depth at 10 $h$. This pattern is not expected from a simple lack of drug penetration since the drug-gradient should have changed during this period. We believe it to be more likely that core cells are intrinsically resistant to apoptosis and die by other mechanisms. Core cells are hypoxic (Figure 1A) and express the ER stress marker Grp78 (our unpublished data). Since apoptosis requires an adequate cellular ATP supply [44], it is interesting to speculate whether cells in the MCS cores are compromized with regard to energy status and unable to undergo apoptosis. If this phenomenon is generally applicable to the response of hypoxic cell populations, apoptosis may not be an adequate read-out for the effects of drugs on solid tumors.

We conclude from this study that cell-based screening using multicellular spheroids identified a novel small molecule with an unprecedented ability to induce apoptosis of 3-D cultured cells. The results show that compounds can be identified that are significantly more powerful than drugs currently used in the clinic. Although the exact mechanism of action of apoptosis induction by NSC647889 is unclear, induction of calcium signaling is likely to be involved. We believe that the identification of drugs that show strong cytotoxic activity on hypoxic and nutrient limited tumor cell populations is a useful strategy for improved treatment of solid tumors.

\section{Competing interests}

The authors declare that they have no competing interests.

\section{Authors' contributions}

\begin{tabular}{|l|c|c|c|c|c|c|c|}
\hline Authors' contributions & STL & CM & WF & MHO & RL & AD & MF \\
\hline Research concept and design & $\checkmark$ & $\checkmark$ & $\checkmark$ & $\checkmark$ & $\checkmark$ & $\checkmark$ & $\checkmark$ \\
\hline Collection and/or assembly of data & -- & $\checkmark$ & $\checkmark$ & $\checkmark$ & -- & -- & $\checkmark$ \\
\hline Data analysis and interpretation & $\checkmark$ & $\checkmark$ & $\checkmark$ & $\checkmark$ & $\checkmark$ & $\checkmark$ & $\checkmark$ \\
\hline Writing the article & $\checkmark$ & $\checkmark$ & $\checkmark$ & $\checkmark$ & $\checkmark$ & $\checkmark$ & $\checkmark$ \\
\hline Critical revision of the article & $\checkmark$ & $\checkmark$ & -- & -- & -- & -- & $\checkmark$ \\
\hline Final approval of article & $\checkmark$ & $\checkmark$ & $\checkmark$ & $\checkmark$ & $\checkmark$ & $\checkmark$ & $\checkmark$ \\
\hline Statistical analysis & $\checkmark$ & $\checkmark$ & -- & -- & -- & -- & $\checkmark$ \\
\hline
\end{tabular}

Acknowledgement

This work was supported by Cancer Society, the Swedish Research Council and Radiumhemmet research funds.

Publication history

EIC: G.J. Peters, VU University Medical Center, Netherlands.

Received: 09-Sep-2013 Revised: 21-Oct-2013

Accepted: 25-Oct-2013 Published: 31-Oct-2013

\section{References}

1. Smalley KS, Lioni M and Herlyn M. Life isn't flat: taking cancer biology to the next dimension. In Vitro Cell Dev Biol Anim. 2006; 42:242-7. I Article I PubMed

2. Sutherland RM, Eddy HA, Bareham B, Reich K and Vanantwerp D. Resistance to adriamycin in multicellular spheroids. Int J Radiat Oncol Biol Phys. 1979; 5:1225-30. | Article I PubMed

3. Tunggal JK, Cowan DS, Shaikh $\mathrm{H}$ and Tannock IF. Penetration of anticancer drugs through solid tissue: a factor that limits the effectiveness of chemotherapy for solid tumors. Clin Cancer Res. 1999; 5:1583-6. I Article | PubMed

4. Tannock IF, Lee CM, Tunggal JK, Cowan DS and Egorin MJ. Limited penetration of anticancer drugs through tumor tissue: a potential cause of resistance of solid tumors to chemotherapy. Clin Cancer Res. 2002; 8:878-84. | Article | PubMed

5. Oloumi A, Lam W, Banath JP and Olive PL. Identification of genes differentially expressed in V79 cells grown as multicell spheroids. Int J Radiat Biol. 2002; 78:483-92. I Article I PubMed

6. Francia G, Man S, Teicher B, Grasso L and Kerbel RS. Gene expression analysis of tumor spheroids reveals a role for suppressed DNA mismatch repair in multicellular resistance to alkylating agents. $\mathrm{Mol}$ Cell Biol. 2004; 24:6837-49. | Article | PubMed Abstract | PubMed Full Text

7. Beningo KA, Dembo $M$ and Wang YL. Responses of fibroblasts to anchorage of dorsal extracellular matrix receptors. Proc Natl Acad Sci U S A. 2004; 101:18024-9. | Article | PubMed Abstract | PubMed Full Text

8. Sutherland RM and Durand RE. Radiation response of multicell spheroids--an in vitro tumour model. Curr Top Radiat Res Q. 1976; 11:87-139. I PubMed

9. Mueller-Klieser W. Multicellular spheroids. A review on cellular aggregates in cancer research. J Cancer Res Clin Oncol. 1987; 113:10122. | Article | PubMed

10. Zietarska M, Maugard CM, Filali-Mouhim A, Alam-Fahmy M, Tonin PN, Provencher DM and Mes-Masson AM. Molecular description of a 3D in vitro model for the study of epithelial ovarian cancer (EOC). $\mathrm{Mol}$ Carcinog. 2007; 46:872-85. | Article I PubMed

11. Padron JM, van der Wilt CL, Smid K, Smitskamp-Wilms E, Backus HH, Pizao PE, Giaccone $G$ and Peters GJ. The multilayered postconfluent cell culture as a model for drug screening. Crit Rev Oncol Hematol. 2000; 36:141-57. | Article | PubMed

12. Brown JM and Wilson WR. Exploiting tumour hypoxia in cancer treatment. Nat Rev Cancer. 2004; 4:437-47. | Article I PubMed 
13. Pampaloni F, Reynaud EG and Stelzer EH. The third dimension bridges the gap between cell culture and live tissue. Nat Rev Mol Cell Biol. 2007; 8:839-45. | Article | PubMed

14. Hirschhaeuser F, Menne H, Dittfeld C, West J, Mueller-Klieser W and Kunz-Schughart LA. Multicellular tumor spheroids: an underestimated tool is catching up again. J Biotechnol. 2010; 148:315. | Article | PubMed

15. Friedrich J, Ebner R and Kunz-Schughart LA. Experimental anti-tumor therapy in 3-D: spheroids--old hat or new challenge? Int J Radiat Biol. 2007; 83:849-71. | Article | PubMed

16. Frankel A, Buckman R and Kerbel RS. Abrogation of taxol-induced G2-M arrest and apoptosis in human ovarian cancer cells grown as multicellular tumor spheroids. Cancer Res. 1997; 57:2388-93. | Article I PubMed

17. Mellor HR and Callaghan R. Resistance to chemotherapy in cancer: a complex and integrated cellular response. Pharmacology. 2008; 81:275-300. | Article | PubMed

18. Herrmann R, Fayad W, Schwarz S, Berndtsson M and Linder S. Screening for compounds that induce apoptosis of cancer cells grown as multicellular spheroids. J Biomol Screen. 2008; 13:1-8. | Article I PubMed

19. Fayad W, Rickardson L, Haglund C, Olofsson MH, D'Arcy P, Larsson $R$, Linder $S$ and Fryknas $M$. Identification of agents that induce apoptosis of multicellular tumour spheroids: enrichment for mitotic inhibitors with hydrophobic properties. Chem Biol Drug Des. 2011; 78:547-57. | Article | PubMed

20. Hagg M, Biven K, Ueno T, Rydlander L, Bjorklund P, Wiman KG, Shoshan $M$ and Linder $S$. A novel high-through-put assay for screening of pro-apoptotic drugs. Invest New Drugs. 2002; 20:253-9. | Article | PubMed

21. Friedrich J, Eder W, Castaneda J, Doss M, Huber E, Ebner R and KunzSchughart LA. A reliable tool to determine cell viability in complex 3-d culture: the acid phosphatase assay. J Biomol Screen. 2007; 12:925-37. | Article | PubMed

22. Lamb J, Crawford ED, Peck D, Modell JW, Blat IC, Wrobel MJ, Lerner J, Brunet JP, Subramanian A, Ross KN, Reich M, Hieronymus H, Wei G, Armstrong SA, Haggarty SJ, Clemons PA, Wei R, Carr SA, Lander ES and Golub TR. The Connectivity Map: using gene-expression signatures to connect small molecules, genes, and disease. Science. 2006; 313:1929-35. | Article | PubMed

23. Olofsson $\mathrm{MH}$, Cummings J, Fayad W, Brnjic $S$, Herrmann R, Berndtsson $M$, Hodgkinson C, Dean E, Odedra R, Wilkinson RW, Mundt KE, Busk $M$, Dive $C$ and Linder $S$. Specific demonstration of drug-induced tumour cell apoptosis in human xenografts models using a plasma biomarker. Cancer Biomark. 2009; 5:117-25. | Article | PubMed

24. Mellor HR, Ferguson DJ and Callaghan R. A model of quiescent tumour microregions for evaluating multicellular resistance to chemotherapeutic drugs. Br J Cancer. 2005; 93:302-9. | Article | PubMed Abstract | PubMed Full Text

25. Fayad W, Brnjic S, Berglind D, Blixt S, Shoshan MC, Berndtsson M, Olofsson $\mathrm{MH}$ and Linder $\mathrm{S}$. Restriction of cisplatin induction of acute apoptosis to a subpopulation of cells in a three-dimensional carcinoma culture model. Int J Cancer. 2009; 125:2450-5. | Article | PubMed

26. Roninson IB. Tumor senescence as a determinant of drug response in vivo. Drug Resist Updat. 2002; 5:204-8. I Article I PubMed

27. Berndtsson M, Hagg M, Panaretakis T, Havelka AM, Shoshan MC and Linder $S$. Acute apoptosis by cisplatin requires induction of reactive oxygen species but is not associated with damage to nuclear DNA. Int I Cancer. 2007; 120:175-80. | Article | PubMed

28. Lukas TJ, Marshak DR and Watterson DM. Drug-protein interactions: isolation and characterization of covalent adducts of phenoxybenzamine and calmodulin. Biochemistry. 1985; 24:151-7. | Article I PubMed

29. Levin RM and Weiss B. Mechanism by which psychotropic drugs inhibit adenosine cyclic 3',5'-monophosphate phosphodiesterase of brain. Mol Pharmacol. 1976; 12:581-9. | Article | PubMed
30. Cheung WY. Calmodulin plays a pivotal role in cellular regulation. Science. 1980; 207:19-27. | Article | PubMed

31. Hegemann L, Toso SM, Lahijani KI, Webster GF and Uitto J. Direct interaction of antifungal azole-derivatives with calmodulin: a possible mechanism for their therapeutic activity. J Invest Dermatol. 1993; 100:343-6. | Article | PubMed

32. Gagliardino JJ, Harrison DE, Christie MR, Gagliardino EE and Ashcroft SJ. Evidence for the participation of calmodulin in stimulus-secretion coupling in the pancreatic beta-cell. Biochem J. 1980; 192:919-27. Pdf | PubMed Abstract | PubMed Full Text

33. Orrenius S, Zhivotovsky B and Nicotera P. Regulation of cell death: the calcium-apoptosis link. Nat Rev Mol Cell Biol. 2003; 4:552-65. I Article I PubMed

34. Kramer G, Erdal H, Mertens HJ, Nap M, Mauermann J, Steiner G, Marberger M, Biven K, Shoshan MC and Linder S. Differentiation between cell death modes using measurements of different soluble forms of extracellular cytokeratin 18. Cancer Res. 2004; 64:1751-6. | Article I PubMed

35. Cummings J, Ward TH, Greystoke A, Ranson M and Dive C. Biomarker method validation in anticancer drug development. $\mathrm{Br} J$ Pharmacol. 2008; 153:646-56. | Article | PubMed Abstract | PubMed Full Text

36. Roufogalis BD, Minocherhomjee AM and Al-Jobore A. Pharmacological antagonism of calmodulin. Can J Biochem Cell Biol. 1983; 61:927-33. | Article I PubMed

37. Martinez-Luis S, Perez-Vasquez A and Mata R. Natural products with calmodulin inhibitor properties. Phytochemistry. 2007; 68:1882-903. | Article | PubMed

38. Liao WC, Huang CC, Cheng HH, Wang JL, Lin KL, Cheng JS, Chai KL, Hsu PT, Tsai JY, Fang YC, Lu YC, Chang HT, Huang JK, Chou CT and Jan CR. Effect of calmidazolium on [Ca2+]i and viability in human hepatoma cells. Arch Toxicol. 2009; 83:61-8. | Article | PubMed

39. Saimi $Y$ and Kung $C$. Calmodulin as an ion channel subunit. Annu Rev Physiol. 2002; 64:289-311. | Article | PubMed

40. Kovalevskaya NV, van de Waterbeemd M, Bokhovchuk FM, Bate N, Bindels RJ, Hoenderop JG and Vuister GW. Structural analysis of calmodulin binding to ion channels demonstrates the role of its plasticity in regulation. Pflugers Arch. 2013. | Article | PubMed

41. Clapham DE. Calcium signaling. Cell. 1995; 80:259-68. | Article | PubMed

42. Clapham DE. Calcium signaling. Cell. 2007; 131:1047-58. | Article | PubMed

43. Brnjic S, Olofsson MH, Havelka AM and Linder S. Chemical biology suggests a role for calcium signaling in mediating sustained JNK activation during apoptosis. Mol Biosyst. 2010; 6:767-74. | Article | PubMed

44. Leist $M$, Single B, Castoldi AF, Kuhnle $S$ and Nicotera P. Intracellular adenosine triphosphate (ATP) concentration: a switch in the decision between apoptosis and necrosis. J Exp Med. 1997; 185:1481-6. | Article | PubMed Abstract | PubMed Full Text

45. Hagg M, Biven K, Ueno T, Rydlander L, Bjorklund P, Wiman KG, Shoshan $\mathrm{M}$ and Linder $\mathrm{S}$. A novel high-through-put assay for screening of pro-apoptotic drugs. Invest New Drugs. 2002; 20:253-9. | Article | PubMed

\section{Citation:}

Mohanty C, Fayad W, Olofsson MH, Larsson R, De Milito A, Fryknäs Mand LinderST. Massiveinduction of apoptosis of multicellular tumor spheroids by a novel compound with a calmodulin inhibitor-like mechanism. J Cancer Ther Res. 2013; 2:19. http://dx.doi.org/10.7243/2049-7962-2-19 